\title{
Impact of Government Measures \\ to Support Mortgage Lending on Housing Affordability in Russia: Regional Evidence
}

\author{
Ianina Roshchina, Lomonosov Moscow State University \\ janina-d@yandex.ru \\ Natalia Ilyunkina, Lomonosov Moscow State University \\ n.ilyunkina@gmail.com
}

This study investigates housing affordability in Russia: factors of affordability, quantitative indicators, and government support measures. We are especially interested in the mortgage rate subsidy programmes that were implemented in 2015-2016 and 2020-2021 and their impact on housing affordability indicators. In order to evaluate impact of the first programme, we use a model of the real estate market and we decompose the index of housing affordability into different factors. As a result of our econometric analysis, we conclude that, in general, the programme was successful. Data about the second programme are not yet sufficient, so we evaluate its impact by a statistical analysis of the dynamics of the main indicators. We conclude that the impact is ambiguous: up until a particular moment (different in different regions), borrowers could benefit from the programme, but after that moment the increase in housing prices caused by the programme itself were exceeding the benefits from the subsidised rates. In conclusion, we provide some recommendations to improve the effectiveness of government measures to support housing affordability, which could be useful in the development of new programmes.

Keywords: housing

affordability, housing market, housing affordability factors, government measures to support housing affordability, subsidised mortgage rates

JEL Codes: $C 10, C 50, R 10, R 21$, R31, G28
Citation: Roshchina, I.

and Ilyunkina, N. (2021). Impact

of Government Measures to Support

Mortgage Lending on Housing

Affordability in Russia: Regional

Evidence. Russian Journal of Money

and Finance, 80(4), pp. 98-123.

doi: $10.31477 /$ rjmf.202104.98

\section{Introduction}

The challenge of housing affordability is relevant in both developing and developed countries, as market mechanisms are often insufficient to solve this 
problem. According to DOM.RF data, $40 \%$ of Russian families would like to improve their living conditions and most of those who desire it cannot buy a home only from their own savings. At the same time, as of $2019,47 \%$ of the population cannot afford to buy a home even with a mortgage (estimation of the Institute for Urban Economics, IUE'1). There, therefore, exist various government programmes in Russia for the improvement of housing affordability, both at the federal and regional levels. The impact of government programmes on housing affordability is not as straightforward as it seems at first glance. They stimulate demand, and, therefore, entail an increase in real estate prices. As a result, housing affordability may decline, contrary to expectations. Additionally, if the share of borrowers with poor solvency grows significantly due to the more attractive mortgage lending conditions, the share of defaults will increase, which will lead to an increase in the risk of financial instability.

Despite the relevance of improving housing affordability, there are not many papers in Russia that investigate the factors of affordability, and, in particular, the results of government programmes. Most Russian authors have carried out statistical analysis of housing affordability indicators without the use of complex econometric methods (Sternik and Apalkov, 2014; Kosareva and Polidi, 2019). Foreign researchers have come to the conclusion that programmes to improve housing affordability affect regions in different ways depending on the population's income level, urbanisation, and other characteristics (Hegedüs et al., 2004; Glaeser and Shapiro, 2002; Hilber and Turner, 2014; Koblyakova et al., 2014). In this paper, we evaluate the impact of the mortgage rate and the related subsidy programmes on the affordability of housing in the regions of Russia.

First of all, it is necessary to define the very concept of housing affordability and the indicators for measuring it. Housing affordability is a complex concept that depends on housing prices, household incomes, mortgage lending conditions, as well as rental and maintenance costs. There is no definition of housing affordability in Russian legislation. In a recent review paper by Galster and Lee (2021), all definitional approaches are combined into four groups.

- Housing is considered affordable if household income, after deducting housing expenses, is sufficient to cover other necessary expenses such as food, clothing, transport, etc.

- Housing is considered affordable if the housing expense to income ratio does not exceed some specified level.

- Housing is considered affordable if a household can afford to spend more than a certain established standard on housing.

- Housing is considered affordable if a household can potentially spend more than a certain established standard on housing while spending no more than a certain fraction of its income.

\footnotetext{
${ }^{1}$ See at https://urbaneconomics.ru/ (in Russian).
} 
There are many indicators of housing affordability. Those most relevant to Russia are regularly calculated by IUE. The generally accepted standard for crosscountry comparisons is the Housing Price-to-Income Ratio $(P I R)$. It is calculated as the ratio of the average price of a $54 \mathrm{sq}$. $\mathrm{m}$. apartment to the average annual income of a family of three:

$$
P I R=\frac{54 \times P}{(3 \times 12 \times \text { Income })},
$$

where $P$ is the average price per 1 sq. $\mathrm{m}$. for real estate and Income is the average monthly income per capita. The Housing Affordability Index (HAI) is a more accurate index that takes into account the possibility of acquiring a home using a mortgage. It is equal to the ratio of household income to the income required to buy a 54 sq. $\mathrm{m}$. apartment using a mortgage, provided that the mortgage payment constitutes $35 \%$ of monthly household income:

$$
H A I=\frac{3 \times \text { Income }}{\left(\frac{L T V \times P \times 54 \times \frac{M R}{12}}{1-\left(1+\frac{M R}{12}\right)^{-12 t}} \times \frac{1}{0.35}\right)},
$$

where Income is the average monthly income per capita, $M R$ is the average annual mortgage rate (as a decimal quantity), $L T V$ is the share of borrowed funds in the price of purchased housing (as a decimal quantity), and $t$ is the average mortgage term in years. Another approach to assessing housing affordability taking mortgage lending into account is to use the indicator of the share of families who have the ability to purchase suitable housing using their own and borrowed funds. To calculate this, the minimum income required to pay monthly mortgage payments is first determined (in this, the mortgage payment must not exceed $35 \%$ of household income):

$$
\text { minIncome }=\frac{L T V \times P \times 54 \times \frac{M R}{12}}{1-\left(1+\frac{M R}{12}\right)^{-12 t}} \times \frac{1}{0.35} .
$$

Knowing the income distribution of the population, it is possible to find the share of households with an income above the calculated minimum. For more accurate estimates, it is better to use the medians rather than averages, since the median is less sensitive to outliers and is better suited for asymmetric distributions such as price and income distributions.

There is still very little Russian data required for this: the IUE is just beginning to calculate indicators based on the median values for Russian agglomerations.

Let us move on to a consideration of the factors of housing affordability. They can all be conditionally divided into three groups (see Figure 1): economic factors, demographic and social factors, and factors of government regulation. 
Figure 1. Factors of housing affordability

\begin{tabular}{|c|c|c|}
\hline Economic factors & $\begin{array}{l}\text { Demographic } \\
\text { and social factors }\end{array}$ & $\begin{array}{l}\text { Factors of government } \\
\text { regulation }\end{array}$ \\
\hline $\begin{array}{l}\text { - Degree of urbanisation } \\
\text { of region } \\
\text { - Competition among } \\
\text { developers } \\
\text { - Degree of development } \\
\text { of mortgage lending } \\
\text { in region } \\
\text { - Inflation } \\
\text { - Wage level } \\
\text { - Inequality level } \\
\text { - Unemployment rate } \\
\text { (Glaeser and Shapiro, 2002; } \\
\text { Skaburskis, 2004; } \\
\text { Hilber and Turner, 2014) }\end{array}$ & $\begin{array}{l}\text { - Population } \\
\text { - Population age structure } \\
\text { - Household size } \\
\text { - Household structure } \\
\text { - Number of children in } \\
\text { household } \\
\text { - Level of education } \\
\text { - Migration indicators } \\
\text { (Bujang et al., 2010; } \\
\text { Caldera Sánchez } \\
\text { and Andrews, 2011) }\end{array}$ & $\begin{array}{l}\text { - Severity of development } \\
\text { restrictions } \\
\text { - Mortgage rate subsidy } \\
\text { programmes } \\
\text { - Down payment subsidy } \\
\text { programmes } \\
\text { - Tax incentives } \\
\text { - Key rate } \\
\text { (Glaeser and Shapiro, 2002; } \\
\text { Hilber and Turner, 2014) }\end{array}$ \\
\hline$\downarrow$ & $\downarrow$ & $\downarrow$ \\
\hline \multirow[t]{3}{*}{$\begin{array}{l}\text { - Housing supply } \\
\text { - Housing demand } \\
\text { (actual household income) }\end{array}$} & - Demand for owned housing & $\begin{array}{l}\text { - Housing supply } \\
\text { - Purchasing power } \\
\text { of population } \\
\text { and its distribution }\end{array}$ \\
\hline & $\downarrow$ & \\
\hline & Housing affordability & \\
\hline
\end{tabular}

Source: compiled by the authors based on literature review

To avoid bias in econometric analysis, the control variables should include factors from each group. Since the factor of interest to us is in the last group, we begin our consideration with government measures aimed at improving housing affordability. These are implemented either directly (for example, by providing subsidies for rent or mortgages) or indirectly (for example, by stimulating housing construction, which in turn should lead to lower prices). Government regulation measures may be aimed at a certain group of citizens: the provision of housing or land to the low-income population, the payment of maternity capital to families with children, a savings and investment system for military personnel, tax deductions for pensioners, etc. The government can also affect the cost of construction by reducing taxes, easing development restrictions, or simplifying legal procedures. Indirect impacts on the housing market may be created by programmes to increase the attractiveness of a region for immigrants, to improve urban areas, or to change utility rates. The existing literature indicates that measures taken are not always successful, contrary to expectations. In the case of Russia, the issue of such impact has been little researched, despite its relevance.

In this paper, we focus on the government policy of the subsidised mortgage rate. The main criticism of programmes to reduce mortgage rates is that they entail an increase in demand (including investment demand), and, consequently, 
an increase in real estate prices. The rise in prices makes it difficult to save a down payment, decreases the availability of mortgages, and increases credit risks. As a result, the initial effect of lowering mortgage rates is partially or completely offset. A research by McGibany and Nourzad (2004) finds a long-term relationship between home prices and mortgage rates. However, at the same time, the elasticity of home prices to the mortgage rate is low, and rates have little short-term impact of on prices. The long-term negative relationship between home prices and mortgage rates is confirmed in more recent studies by Damen et al. (2016) and McQuinn and O'Reilly (2008). Hilber and Turner (2014), using the US data, find that interest payment subsidies help to increase the provision of housing only to high-income households in areas without tight housing market regulation. The authors believe that in more urbanised regions with severe urban planning restrictions the housing supply elasticity is low, which means that subsidies will be capitalised in price increases. In areas with weaker development control and elastic housing supply, the effect of lower mortgage rates on housing affordability will be positive. Glaeser and Shapiro (2002) find that mortgage rate subsidies have a positive impact on housing availability in high-price regions where young, high-income homeowners live. A paper by Hegedüs et al. (2004) compares the impact of interest rate subsidies and down payment subsidies on housing affordability and mortgage demand (data for Budapest and Moscow). Down payment subsidies are found to stimulate purchasing power better than interest rate subsidies in terms of effectiveness and the distribution of subsidies to middle-income families. The authors believe that the main problem preventing households from purchasing housing is a lack of savings. Donner (2000) consider the measure of home mortgage interest deductions. He questions its effectiveness: the higher a person's income, the greater the size of the tax deduction that he or she can claim, and, therefore, the greatest benefit from the introduction of a tax deduction is received by the part of the population that least needs it. Another approach to improving housing affordability is the development of the rental housing market. In Russia, this approach is not common, but some Eastern European countries (Poland, the Czech Republic, Slovenia) have had government subsidies that contributed to the construction of government-owned rental housing (Hegedüs et al., 2011), although in recent years this measure has been inferior to standard measures to increase the level of home ownership.

Let us turn to a discussion on the economic and social and demographic factors of housing affordability. First of all, we note that the mortgage lending and residential real estate markets are closely interconnected. Thus, a rise in real estate prices has a positive effect on the volume of mortgage loans, since households need more funds to buy housing. In addition, observing the rise in prices, households can expect further increases and thereby increase the demand for mortgage lending. This growth in demand, in turn, stimulates the growth of real estate prices, which leads to a deterioration in housing affordability (Anundsen and Jansen, 2013; Basten and Koch, 2015). This result is confirmed in a paper by Sternik 
and Apalkov (2014), who come to the conclusion that household income affects housing affordability the most, followed by real estate prices and, after them, the mortgage rate. Housing prices can be affected by factors such as the size of the city or town, the age of the housing stock, construction costs, land and electricity prices, the wage level, the cost of materials, and the cost of legal support. The literature notes the role of income inequality in society. With strong polarisation of income, the poor cannot participate in the housing market, and as a result such people move, move in with others, or become homeless (Skaburskis, 2004). There are a number of papers devoted to the analysis of the effect of the demographic characteristics of the population on housing affordability. Rosen (1979) identifies household income per person, the gender of heads of household, household age structure and size, and education as such factors. Economists who have studied housing affordability in Malaysia (Bujang et al., 2010) find a significant impact from such factors as the size and age structure of a household, its level of education and income, and the marital status of its members. Since young families are more likely to purchase apartments, an additional factor is the share of such families in the total population ( $\mathrm{Li}$ and Chand, 2013). Migration is an indicator of how much people wish to live in a given region. There is still no consensus on the relationship between migration and real estate prices. On the one hand, with an increase in the number of immigrants, the demand for real estate increases (Mussa et al., 2017), but, on the other hand, the attractiveness of the region for the native population decreases (Sá, 2015).

Based on this review, we put forward and test the following hypotheses.

- A reduction in mortgage rates raises real estate prices.

- Mortgage rate subsidy programmes do not improve housing affordability, since the initial effect of an increase in the availability of credit funds is offset by a decrease in the price affordability of housing.

\section{Mortgage lending and housing affordability in Russia}

The development of mortgage lending is one of the main methods to improve housing affordability, but it is not as popular in Russia as in the developed countries: the mortgage loan debt of Russians, according to data for 2019, amounted to $7.8 \%$ of GDP. Despite the upward trend (in 2020, the indicator increased significantly and approached $8 \%$ of GDP), this value remains significantly lower than the same indicator for the developed countries (according to EMF Hypostat data ${ }^{2}$, on average, in the European Union, mortgage debt in 2019 amounted to $44.1 \%$ of GDP). The main reasons for this are the high mortgage rates, the low household incomes, and the high housing prices in Russia. Also, the peculiarities of the Russian market include the low level of trust in the banking sector, the significant share of shadow

\footnotetext{
${ }^{2}$ See at EMF Hypostat website, https://hypo.org/ecbc/publications/hypostat/\#
} 
income, and the low levels of savings, investment activity, and financial literacy of the population. Nevertheless, there has been an increase in the number and volume of mortgage loans issued in Russia. Figure 2 shows the decline in 2015 caused by the financial crisis, and there is also a negative relationship between the value of the interest rate and the volume of loans issued. In 2020, the volume of loans issued amounted to more than 4.3 trillion roubles, of which 1.1 trillion roubles were loans issued under the preferential mortgage programme at $6.5 \%$ per annum (Consulting Center DOM.RF, 2021).

Figure 2. Dynamics of mortgage loans issued and mortgage rates

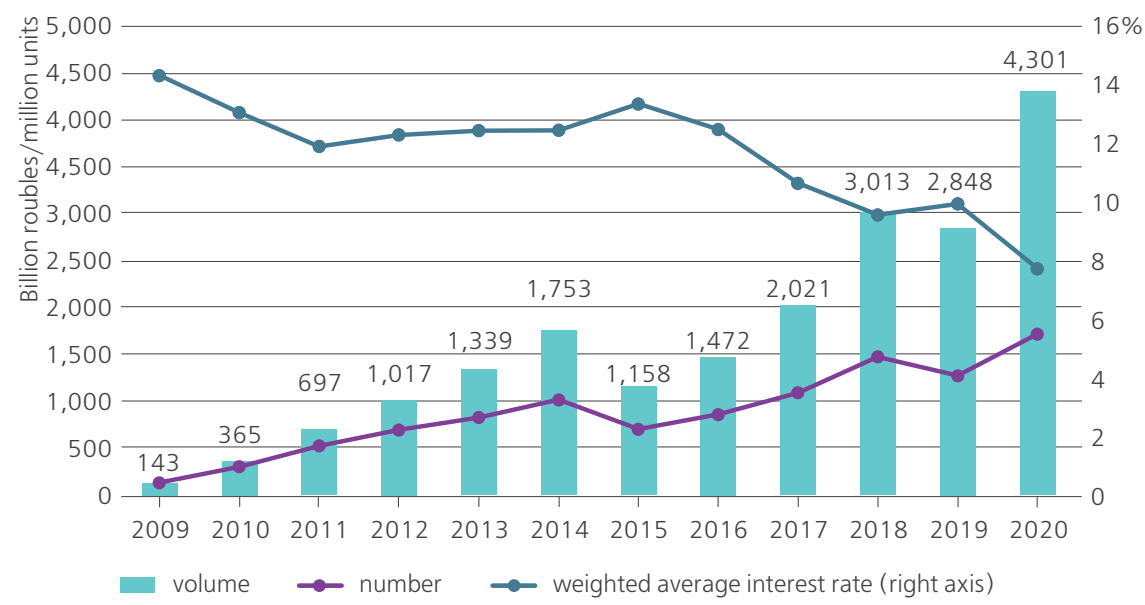

Source: compiled by the authors based on data from the Bank of Russia

Mortgage loans are issued most often in the Central Federal District (in 2020, more than one third of all loans issued). Breaking down by region, the highest numbers are in Moscow, Moscow Region, St. Petersburg, and Tyumen Region. In terms of volumes most of the loans are issued by banks located in the Central Federal District, as well as in the Northwestern Federal District, where VTB's head office is located (the bank holds $22 \%$ of the volume of loans issued in 2020, which is second place, after Sberbank with 48\%). In general, in Russia, as in many countries, there are processes of centralisation and concentration underway in the banking system, which also affects the mortgage market: in 2020, five banks (Sberbank, VTB, Russian Agricultural Bank, Alfa-Bank, and Otkritie FC) issued more than $80 \%$ of the volume of mortgage loans (Filippova, 2021).

Moving on to the indicators of housing affordability, we note that both the share of families with the ability to purchase housing and the HAI show an upward trend (Figure 3). The HAI is subject to seasonal fluctuations due to the pronounced seasonality of the average per capita income. Growth of both indicators accelerated in 2017. 
Figure 3. Dynamics of average housing affordability indicators for Russia

Share of families with the ability

to purchase housing, \%

60

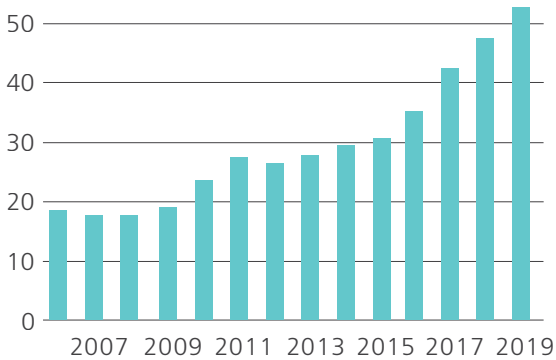

Housing Affordability Index, \%

200
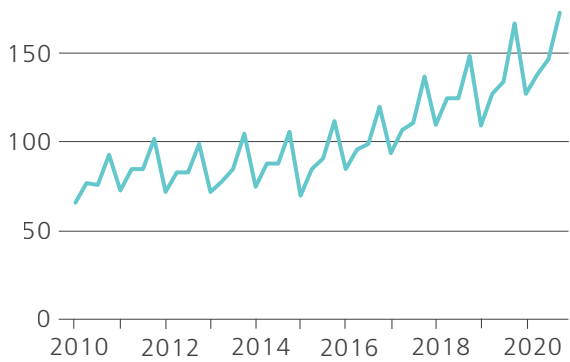

Source: before 2020, the IUE; for 2020, calculated by the authors according to Rosstat data using the IUE methodology

Figure 4. Ratio of price of 1 sq. m. to GDP per capita as of beginning of $2021, \%$

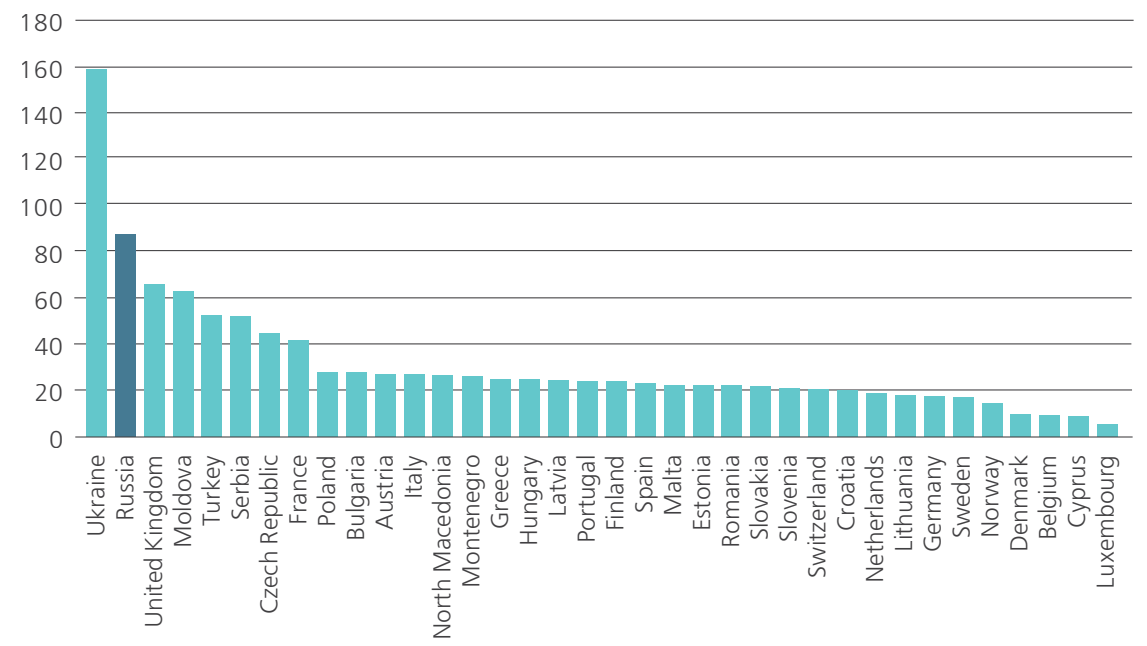

Source: Global Property Guide

However, these indicators do not take into account the size of the down payment or the differences in housing prices and incomes between regions. Also, not every family satisfies the prerequisites laid down in the calculation (it should consist of three people with the national average income). And even if a family does satisfy the conditions, its residual income after deducting the mortgage payments makes it possible to cover only necessary expenses (Kosareva and Polidi, 2019). To speak about the current situation, we note that, at the beginning of 2021, Moscow ranked first among European cities in terms of the ratio of the median price of a 90 sq. $\mathrm{m}$. apartment to the median family income 
(PIR), ${ }^{3}$ which indicates the extremely low housing affordability in the capital. The ratio of the price of 1 sq. $\mathrm{m}$. to GDP per capita (an indicator similar to the PIR) is used for cross-country comparisons. According to the data for the beginning of 2021, the value of this indicator in Russia is one of the highest among European countries $\left(87.4 \%,{ }^{4}\right.$ see Figure 4$)$.

This situation is largely due to the low incomes of the population: according to the International Monetary Fund, ${ }^{5}$ GDP per capita in Russia is $\$ 11,650$, while the average for Europe is $\$ 31,750$. At the same time, the price of real estate in Russia is higher than the European average. The Global Property Guide home price data is calculated for 120 sq. m. in the centre of the country's main city (capital or financial centre), which allows them to be used for cross-country comparisons. So, we can conclude that the situation of housing affordability in Russia is not critical, but it is noticeably worse than in the developed European countries.

Among the measures currently used in the Russian Federation to improve housing affordability, we can single out measures related to increasing the availability of mortgage lending. They, in turn, can be divided into the following groups according to their mechanism of impact:

- Down payment subsidy (Young Family, maternity capital, subsidies to large families),

- Mortgage rate subsidy (Family Mortgage, Far Eastern Mortgage, Preferential Mortgage at 6.5\%),

- Mortgage payment subsidy (Military Mortgage),

- Provision of tax incentives (for the purchase and sale of housing, for mortgage interest payments),

- Provision of mortgage payment holidays.

Next, we consider the two major federal mortgage rate subsidy programmes. The first programme (the Government Programme for Subsidising Interest Rates on Mortgage Loans for the Purchase of Housing Under Construction, see Russian Government, 2015) was aimed at supporting demand for mortgage lending during the crisis period, when the Bank of Russia decided to raise the key rate from $10.5 \%$ to $17 \%$ due to the risk of devaluation of the ruble and panic in the foreign exchange market. This decision led to an increase in the mortgage rate to values of over $20 \%$ per annum. Under the programme, rates were not to exceed $12 \%$, provided that the borrowers had taken out personal and home insurance policies. Despite the programme, the volume of mortgage loans issued in 2015 decreased by almost 0.6 trillion roubles compared with 2014 and returned to the pre-crisis

\footnotetext{
${ }^{3}$ Numbeo, https://www.numbeo.com/property-investment/region_rankings.jsp?title=2020mid\&region=150 (accessed on 12 July 2021). Numbeo is a crowdsourced database on the quality of life of the populations of the countries of the world. In the absence of other sources with comparable PIR values for a large sample of countries, the probable errors can be ignored and assumed to be small relative to the size of the base.

${ }^{4}$ See https://www.globalpropertyguide.com/Europe/price-gdp-per-cap (accessed on 14 July 2021).

${ }^{5}$ See at https://www.imf.org/external/datamapper/NGDPDPC@WEO/EUQ/RUS (accessed on 14 July 2021).
} 
level only in 2017. The second programme (Preferential Mortgage at 6.5\%, see Russian Government, 2020) was adopted to prevent a decline in demand caused by the epidemic and quarantine, and set a record in terms of the volume of loans. Any citizen of the Russian Federation could take a loan to purchase housing on the primary market at a rate of $6.5 \%$ from April 2020 to June 2021.

Figure 5. Quarterly dynamics of the volume and number of mortgage loans issued

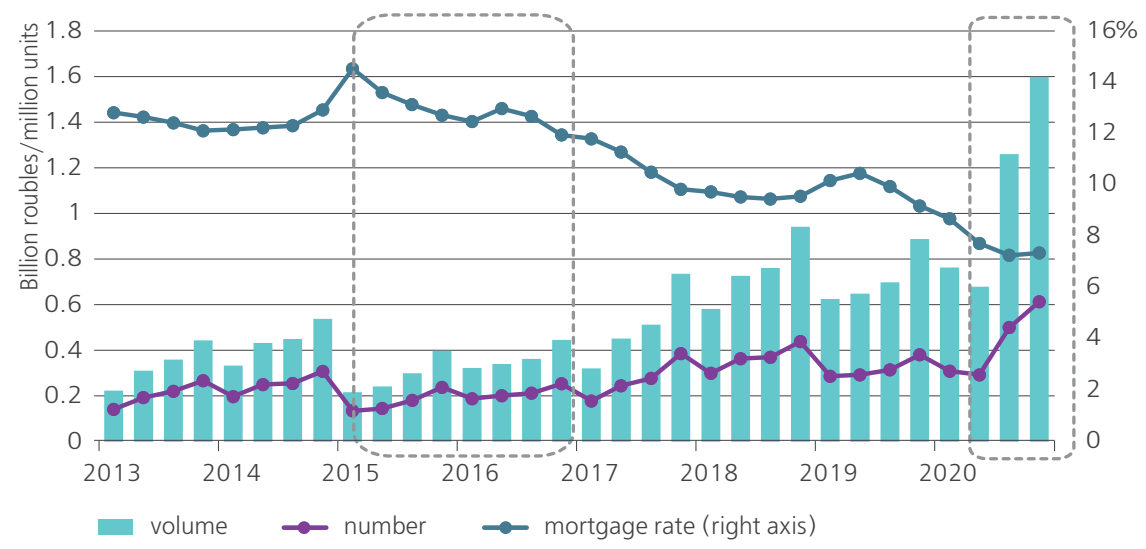

Source: compiled by the authors based on data from the Bank of Russia

Figure 5 shows the periods for both programmes. In 2015-2016, the demand for mortgage loans remained almost unchanged; in 2020, on the contrary, sharp growth was observed. It should be noted that the first programme was introduced against a background of record high key rate values, while the second one, during a decline to the lowest values ever. Below are the methodologies for evaluating both programmes.

\section{Methodology for evaluating the impact of the 2015-2016 preferential mortgage programme on housing affordability}

The effects of the 2015-2016 programme can be estimated using regression analysis, since it is already possible to find a sufficient amount of data on the periods before the start of the programme and after its completion. All of the indicators of housing affordability discussed above are calculated on the basis of interrelated values, such as mortgage rate and real estate price. Therefore, an attempt to directly use any of the indicators of housing affordability as dependent variables leads to the fact that none of the used for constructing the indicator can be included in the right-hand side of the regression. In order to get out of this situation, we first evaluate the impact of the subsidy programme on the price of real estate to understand how much prices changed due only to the 
implementation of the programme. After that, we decompose the HAI into factors and compare the contribution of the decrease in the mortgage rate and the contribution of the increase in real estate prices caused by the implementation of the programme to the change in the HAI. Then, we compare the effects of the price increase and the rate cut and draw a general conclusion about the positive or negative impact of the programme.

Data for some indicators are available only on an annual basis, so we use annual data from 2010 to 2019 for the Russian regions. Earlier years are not included in the analysis, first, due to a lack of data, and second, because of a possible structural shift caused by the financial crisis of 2008-2009. The period from 2010 to 2019 was relatively stable, apart from the 2014-2015 currency crisis, which affected the real estate market through a decrease in investment and housing commissioning and an increase in interest rates. These and other factors are taken into account using control variables.

The real estate price is formed as a result of the interaction of supply and demand. The authors of similar studies have come to the conclusion that the method of instrumental variables is the most suitable method for analysing pricing in the real estate market using short panel data (Drobyshevsky et al., 2009; Li and Chand, 2013). We do the same and define the supply $\left(Q_{i t}^{S}\right)$ and demand $\left(Q_{i t}^{D}\right)$ functions for housing in region $i$ in year $t$ as follows:

$$
\begin{gathered}
Q_{i t}^{S}=f_{1}\left(P_{i t}, \text { Inv }_{i t}, \text { Houses }_{i t}, \text { Cert_ind }_{i t}, \text { Incomp }_{i t}\right), \\
Q_{i t}^{D}=f_{2}\left(P_{i t}, \text { Income }_{i t}, M R_{i t}, \text { Ineq }_{i t}, H_{-} \text {fund }_{i t}, \text { Incomp }_{i t}\right),
\end{gathered}
$$

where Inv $v_{i t}$ is the volume of fixed capital investment, Houses ${ }_{i t}$ is the rate of housing commissioning, $P_{i t}$ is the average price of housing per 1 sq. m., Cert_ind is an index of entrepreneurial confidence in construction which is equal to the arithmetic mean of the 'balances' of estimates of the order portfolio and the expected change in the number of employees, ${ }^{6}$ Incomp $_{i t}$ is the area of the apartments in residential buildings under construction, Income $_{i t}$ is the average per capita income, $M R_{i t}$ is the weighted average mortgage rate, Ineq ${ }_{i t}$ is the Gini coefficient, and $H_{-}$fund $_{i t}$ is the total living space per person.

We equate supply and demand and use a Two-Stage Least Squares method (2SLS) with instruments Inv ${ }_{i t}$, Houses ${ }_{i t}$, Cert_ind ${ }_{i t}$, Incomp $_{i t}$. They are relevant (the corresponding F-statistic is greater than 10, see Table 1). The exogeneity of the instruments chosen follows from two considerations. The first consideration is content-related: the index of entrepreneurial activity is calculated on the basis of surveys of the heads of construction companies (see, e.g., Higher School of Economics, 2019), so we think that developers are guided by it, that is, by the supply of residential construction. The second consideration is technical: the

\footnotetext{
${ }^{6}$ See at https://www.fedstat.ru/opendata/7708234640-threeathreeasixafouraeight (in Russian).
} 
Sargan test was carried out, and the p-value turned out to be 0.2 , that is, the hypothesis of the exogeneity of the instruments is accepted.

In the first stage, we estimate the regression of the supply of housing on the instruments and the exogenous variables:

$$
\begin{gathered}
\text { All_rights_p }_{i t}=\alpha_{1} \times \text { Inv }_{i t}+\alpha_{2} \times \text { Houses }_{i t}+\alpha_{3} \times \text { Cert }_{\text {ind }} \text { it } \\
+ \\
+\alpha_{4} \times \text { Incomp }_{i t}+\alpha_{5} \times \text { Income }_{i t}+\alpha_{6} \times M R_{i t} \\
+\alpha_{7} \times \text { Ineq }_{i t}+\alpha_{8} \times H_{-} \text {fund }_{i t}+\alpha_{9} \times \text { People_num }_{i t} \\
+\alpha_{10} \times \text { Infl }_{i t}+\alpha_{11} \times \text { Urb }_{i t}+\alpha_{12} \times \text { Migr }_{i t}+\varepsilon_{i t} .
\end{gathered}
$$

In equilibrium, $Q_{i t}^{D}=Q_{i t}^{S}=A l l_{-} r i g h t s_{-} p c_{i t}$, where $A l l_{-} r i g h t s_{-} p c_{i t}$ is the number of registered property titles to residential premises. We expect that the supply of housing positively depends on the rate of housing commissioning, confidence in the construction sector, and the area under construction, and negatively depends on fixed capital investment (a proxy variable for the developer's costs). All variables are normalised for the population so that it can be identified as a separate factor. In the second stage, we estimate the following regression:

$$
\begin{aligned}
P_{i t}=\beta_{0}+\beta_{1} \times \text { All_rights_p }_{\text {rt }}+\beta_{2} \times \text { Income }_{i t}+\beta_{3} \times M R_{i t} \\
+\beta_{4} \times \text { Ineq }_{i t}+\beta_{5} \times H_{-} \text {fund }_{i t}+\beta_{6} \times \text { People_num } \\
\\
+\beta_{7} \times \text { Infl }_{i t}+\beta_{8} \times \text { Urb }_{i t}+\beta_{9} \times \text { Migr }_{i t}+u_{i t} .
\end{aligned}
$$

We expect that demand for housing depends positively on income per capita and depends negatively on income inequality, mortgage rates, and living space per person. The following control variables are also included in the equation: inflation rate $I n f l_{i t}$, level of urbanisation $U r b_{i t}$, and migration growth coefficient $M_{i g r}$.

A natural cut in the interest rate (in response to a change in the key rate or a decrease in the stability of the financial sector) and a forced cut in the interest rate (as a result of the implementation of the federal programme) may affect the price of real estate in different ways. In order to separate these two effects, we decompose the interest rate into two components:

$$
M R_{i t}=M R_{i t}^{p o t}-\Delta M R_{i t},
$$

where $M R_{i t}^{\text {pot }}$ is the potential average mortgage rate in the absence of the programme. According to the Russian Government Resolution (2015) on the Rules for Granting Subsidies, DOM.RF reimbursed banks for lost income up to the level of the Bank of Russia key rate $\left(R A T E_{t}\right)$, plus 3.5 percentage points (pp). Therefore, we assume further that the Bank of Russia expected that, in the absence of the programme, banks would set their rates $3.5 \mathrm{pp}$ higher than the key rate. Mortgage rates in the secondary housing market are usually slightly higher than the rates in the primary housing market, so our estimate of the effect of the 
programme may be slightly underestimated. The potential average mortgage rate in the absence of the programme is equal to:

$$
M R_{i t}^{p o t}=R A T E_{t}+3.5
$$

The interest rate cut caused by the implementation of the programme is:

$$
\Delta M R_{i t}=M R_{i t}^{p o t}-M R_{i t}=R A T E_{t}+3.5-M R_{i t} .
$$

For ease of interpretation, the interest rate cut $\Delta M R_{i t}$ is multiplied by $(-1)$, and then we can expect that both components of $M R_{i t}$ negatively affect the price of housing. Figure 6 shows the dynamics of the average mortgage rate in Russia, the average key rate (before September 2013, the refinancing rate), the potential rate in the absence of the programme, and the yield on 10-year bonds (closely correlated with the mortgage rate). In mid-December 2014, there was a sharp increase in the key rate (from $10.5 \%$ per annum to $17 \%$ to prevent the depreciation of the ruble, which is the largest change in the entire history of its existence), and, consequently, an increase in the potential mortgage rate.

Figure 6. Dynamics of potential and real mortgage rates

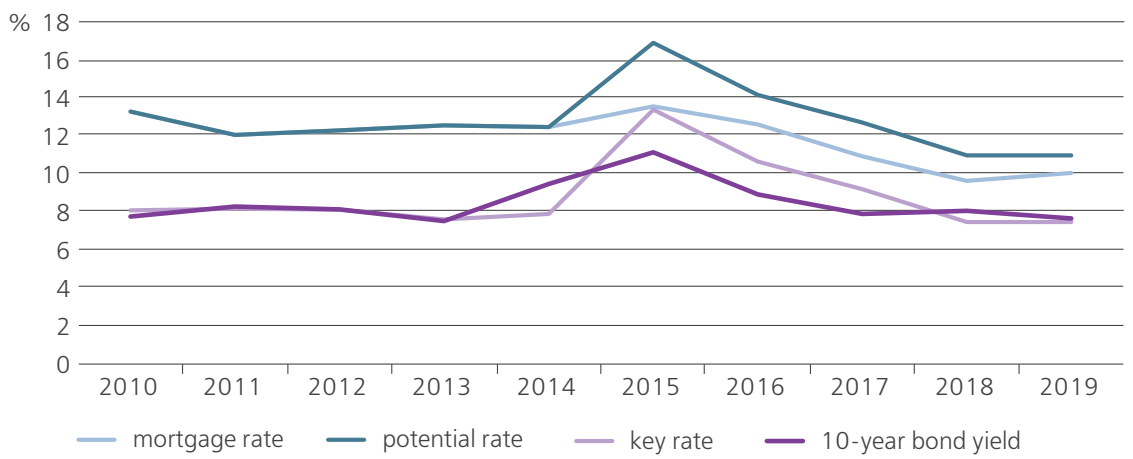

Source: compiled by the authors based on data from the Bank of Russia

In order to account for the heterogeneity of regions, we use fixed or random effects. To test our hypothesis of the differing impact of the programme depending on the levels of urbanisation and income, we evaluate the model on various subsamples of regions. To test the robustness of the results, we estimate a regression built by analogy with Shi et al. (2014). According to a number of researchers (Li and Chand, 2013; Shi et al., 2014; Fingleton et al., 2019; DiPasquale and Wheaton, 1994), the amount of supply and housing prices change slowly, and one year is not enough to establish equilibrium, therefore it is necessary to take into account the price adjustment mechanism and to add the price of the previous period to the right-hand side of the demand equation. In this case, the generalised method of moments (GMM) should be used to avoid the problem of autocorrelated errors. The price adjustment mechanism is described by the following equation: 


$$
P_{t}=\tau \times P_{t}^{*}+(1-\tau) \times P_{t-1}
$$

where $P_{t}^{*}$ is the equilibrium price.

Given these prerequisites, the regression equation for checking the robustness of the results using GMM is as follows:

$$
\begin{aligned}
& P_{i t}=\beta_{0}+\beta_{1} \times P_{i t-1}+\beta_{2} \times \text { Income }_{i t}+\beta_{3} \times M R_{i t}+\beta_{4} \times \text { Ineq }_{i t} \\
& +\beta_{5} \times H_{-} \text {fund }_{i t}+\beta_{6} \times \text { People_num } i t+\beta_{7} \times I n f l_{i t}+\beta_{8} \times U r b_{i t} \\
& +\beta_{9} \times \operatorname{Migr}_{i t}+\beta_{10} \times A l l \_r \widehat{g h t} \_p c_{l t}+u_{i t} \text {. }
\end{aligned}
$$

In the first stage, we re-estimate equation (6) using the Blundell-Bond system GMM estimator. Its special feature is that, in addition to lagged values, the first differences are used as instruments, which makes the instruments stronger and increases the efficiency of estimation.

One factor that indirectly affects the demand for real estate during the programme period is the general state of the country's economy (the unemployment rate, the oil price, and the imposition of financial and economic sanctions). It affects purchasers' expectations and their confidence in the future, and, therefore, their willingness to take out mortgages. Therefore, in order to correctly evaluate the effect of the programme, equations (7) and (12) include the income of the population, inflation, and the unemployment rate (this last variable later turned out to be insignificant; therefore, it was not included in the final equation). Also, precisely for the purpose of taking into account the state of the economy, the index for entrepreneurial confidence in construction is included in equation (6). This variable is used in the supply equation, but it also characterises the expected demand from the population and its reaction to the crisis (the inclusion of a similar consumer confidence index in the demand equation did not affect the values of the coefficients for the other variables; therefore, it is not reflected in the final model).

The proposed design for econometric modelling allows the accounting for the peculiarities of the regions, changes in macroeconomic indicators, changes in consumer expectations caused by the crisis, as well as allows the verification of the robustness of the inference, the obtaining of estimates for different subsamples of regions, and the clearing of the price change from the impact of other factors (including the impact of the crisis) due to the implementation of the programme.

\section{Methodology for summing up the preliminary results of the 2020-2021 programme}

It is too early to draw final conclusions about the impact of the 2020-2021 programme, since it was in effect until 1 July 2021,7 so we carry out a statistical analysis. To begin, let us look at the dynamics of the classic indicator of affordability,

\footnotetext{
${ }^{7}$ In the beginning of 2021 the programme was extended to 1 July 2022 under the different conditions: the mortgage of $7 \%$ and the credit limit of three million roubles.
} 
the HAI (see (2) formula). In its calculation, the size of the down payment does not play as significant a role as the size of monthly payments, and the possible difficulties of a family may have with saving it are not taken into account. In order to take into account both parameters, we use an indicator of the total costs of acquiring housing, equal to the sum of the principal amount, the interest and the down payment

$$
\text { Total costs }=12 \times t \times x+(1-L T V) \times P,
$$

where $x$ is the monthly annuity payment, $t$ is the loan term in years, LTV is the ratio of debt to the price of housing, $P$ is the price of housing, and $M R$ is the mortgage rate in percent per annum. The value of the monthly annuity payment is calculated using the following formula:

$$
x=L T V \times P \times \frac{\frac{M R}{12} \times\left(1+\frac{M R}{12}\right)^{12 \times t}}{\left(1+\frac{M R}{12}\right)^{12 \times t}-1} .
$$

Next, we consider the change in two important indicators: the HAI and the total cost of purchasing a home on a mortgage. However, these can also be criticised, because, for example, they do not take into account the propensity of the population to save and are based on average or median housing prices, and, therefore, do not take into account the diversity of supply in the housing market.

\section{Discussion and analysis of the findings of econometric estimation of the impact of the 2015-2016 government programme on housing prices and affordability}

In order to evaluate the impact of the 2015-2016 government programme, we use the model described above on panel data for the regions of Russia from 2010 to 2019, where all values are taken in nominal terms. The definitions of the indicators and the sources of data can be found in Appendix A (see the online version of this paper), and descriptive statistics of the variables can be found in Appendix B. The econometric modelling was carried out in the R language: the plm and ivpack packages were used to build the models, the lmtest package was used to conduct the tests, the ggplot 2 and corrplot packages were used for plotting, and the readxl package was used to read the data. Preliminary analysis of the data was carried out using correlation matrix estimation (see Appendix B) and scatter plots. The signs of most of the paired correlation coefficients coincide with the preliminary expectations. For example, the price of real estate is positively correlated with the average income per capita, the level of urbanisation, the population, the number of registered titles to residential premises and the coefficient of migration growth. The unit root test results (Maddala and $\mathrm{Wu}, 1999$ ) indicated stationarity of the model variables ( $\mathrm{p}$-value $<0.01$, the alternative hypothesis is that the series is stationary). The sample was adjusted: due to gaps in the data, Ingushetia, Magadan and 
Murmansk Regions, the Nenets Autonomous Area and the regions of the Crimean Federal District were excluded. Moscow and Sakhalin Region were also not taken into account, since they differ greatly from other regions in terms of real estate prices.

Figure 7. Scatter plot

a) full sample scatter plot

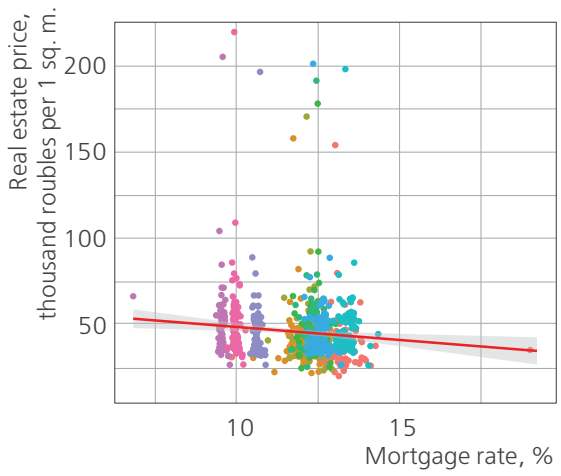

b) adjusted sample scatter plot

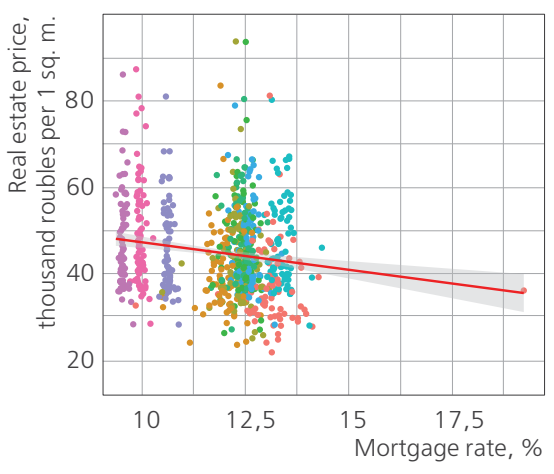

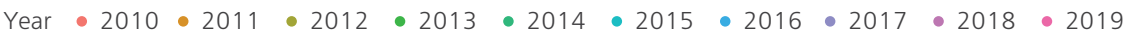
Source: compiled by the authors using the R environment

As an indicator of the number of transactions in the real estate market, we use variableAll_rights_pc, which shows the total number of registered titles to residential premises per person. In the first stage, we estimate the number of transactions using (6), and in the second stage, the inverse demand function (7). If we use the real estate price index as a dependent variable or build a model in first differences, the signs of the coefficients remain the same, but the quality of the model deteriorates, so we will focus on the model design proposed above. We estimate the model in several specifications: without taking into account the panel structure (Pooled), with regional fixed effects (FE), with random effects (RE1 and RE2 with different interest rate variables), and the GMM. All regressions use the instruments described above for the logarithm of the number of registered titles to residential premises $\log \left(A l l \_r \hat{i g h t} \_p c\right)$. The Hausman (p-value $=0.84$ ) and Breusch-Pagan ( $\mathrm{p}$-value $<0.01$ ) tests indicate the choice of a random effects model (similar to the results of Fingleton et al., 2019). The model with random effects requires the fulfilment of a larger number of prerequisites, but also it has its advantages: when using it, there is no significant loss of degrees of freedom, as in the model with fixed effects, which includes many binary variables. According to the test statistics (Section 3) the instrumental variables are exogenous and relevant, and the signs in the first-stage regression are in line with our expectations. The absence of multicollinearity was confirmed using Variance Inflation Factors (VIF).

The estimate of the coefficient for the mortgage rate in the second stage regressions (7) varies from -0.056 to -0.036 , which confirms the hypothesis of its negative impact on real estate prices. The coefficients for the potential mortgage 
rate $\left(M R \_p o t\right)$ and the rate cut $\left(M R \_d i f\right)$ are also negative, with the effect of natural rate changes being greater than the effect of rate changes due to the implementation of the programme. The coefficients for both variables are significant at the $10 \%$ level and differ by 0.012 . When the mortgage rate is decomposed into two components, the quality of the model improves (based on the adjusted $R^{2}$ ). Thus, a 1 pp decrease in mortgage rates leads to an increase in real estate prices by $3.6-6 \%$. From the best specification (RE2), it follows that a mortgage rate subsidy of 3.5 pp leads to a $10.5 \%$ increase in real estate prices.

Table 1. Results of estimation of real estate price model

\begin{tabular}{|c|c|c|c|c|c|}
\hline \multicolumn{6}{|c|}{ The dependent variable is the logarithm of the average real estate price } \\
\hline & Pooled & FE & RE1 & RE2 & GMM \\
\hline $\log ($ Income $)$ & $\begin{array}{l}0.547^{* * *} \\
(0.038)\end{array}$ & $\begin{array}{l}0.333^{* * *} \\
(0.067)\end{array}$ & $\begin{array}{l}0.434^{* * *} \\
(0.030)\end{array}$ & $\begin{array}{l}0.471^{* * *} \\
(0.031)\end{array}$ & $\begin{array}{l}-0.057 \\
(0.030)\end{array}$ \\
\hline $\log ($ Ineq $)$ & $\begin{array}{l}-0.015 \\
(0.144)\end{array}$ & $\begin{array}{l}-0.058 \\
(0.255)\end{array}$ & $\begin{array}{l}-0.168 \\
(0.158)\end{array}$ & $\begin{array}{l}-0.191 \\
(0.145)\end{array}$ & $\begin{array}{l}0.316^{* * *} \\
(0.087)\end{array}$ \\
\hline $\log (\operatorname{Infl})$ & $\begin{array}{l}0.684^{* *} \\
(0.279)\end{array}$ & $\begin{array}{l}0.655^{* * *} \\
(0.170)\end{array}$ & $\begin{array}{l}0.568^{* * *} \\
(0.181)\end{array}$ & $\begin{array}{l}0.559^{* * *} \\
(0.164)\end{array}$ & $\begin{array}{l}0.745^{* * *} \\
(0.067)\end{array}$ \\
\hline $\log \left(H_{-}\right.$fund $)$ & $\begin{array}{l}-0.480^{* * *} \\
(0.077)\end{array}$ & $\begin{array}{l}0.235 \\
(0.273)\end{array}$ & $\begin{array}{l}-0.168 \\
(0.132)\end{array}$ & $\begin{array}{l}-0.144 \\
(0.121)\end{array}$ & $\begin{array}{l}-0.107^{* *} \\
(0.036)\end{array}$ \\
\hline $\log ($ People_num $)$ & $\begin{array}{l}0.023^{*} \\
(0.012)\end{array}$ & $\begin{array}{l}-0.738 \\
(0.568)\end{array}$ & $\begin{array}{l}0.027 \\
(0.029)\end{array}$ & $\begin{array}{l}0.030 \\
(0.027)\end{array}$ & $\begin{array}{l}0.001 \\
(0.008)\end{array}$ \\
\hline Migr & $\begin{array}{l}0.001^{* * *} \\
(0.0002)\end{array}$ & $\begin{array}{l}0.001^{*} \\
(0.0004)\end{array}$ & $\begin{array}{l}0.001^{* * *} \\
(0.0002)\end{array}$ & $\begin{array}{l}0.001^{* * *} \\
(0.0002)\end{array}$ & $\begin{array}{l}0.000 \\
(0.000)\end{array}$ \\
\hline$M R$ & $\begin{array}{l}-0.056^{* * *} \\
(0.016)\end{array}$ & $\begin{array}{l}-0.049^{* * *} \\
(0.011)\end{array}$ & $\begin{array}{l}-0.055^{* * *} \\
(0.010)\end{array}$ & & $\begin{array}{l}-0.038^{* * *} \\
(0.003)\end{array}$ \\
\hline MR_pot & & & & $\begin{array}{l}-0.041^{\star * *} \\
(0.012)\end{array}$ & \\
\hline MR_dif & & & & $\begin{array}{l}-0.029^{*} \\
(0.015)\end{array}$ & \\
\hline $\log ($ All_rights_pc $)$ & $\begin{array}{l}0.504^{* * *} \\
(0.133)\end{array}$ & $\begin{array}{l}0.477^{* * *} \\
(0.110)\end{array}$ & $\begin{array}{l}0.476^{* * *} \\
(0.090)\end{array}$ & $\begin{array}{l}0.412^{\star * *} \\
(0.090)\end{array}$ & $\begin{array}{l}0.156^{* * *} \\
(0.024)\end{array}$ \\
\hline Constant & $\begin{array}{l}5.230^{* * *} \\
(1.331)\end{array}$ & & $\begin{array}{l}5.526^{* * *} \\
(0.974)\end{array}$ & $\begin{array}{l}4.738^{* * *} \\
(0.972)\end{array}$ & \\
\hline Avg_price $(t-1)$ & & & & & $\begin{array}{l}0.764^{* * *} \\
(0.045)\end{array}$ \\
\hline Number of observations & 704 & 704 & 704 & 704 & 760 \\
\hline$R^{2}$ & 0.500 & 0.412 & 0.816 & 0.844 & \\
\hline Adjusted $R^{2}$ & 0.494 & 0.333 & 0.813 & 0.842 & \\
\hline Residual standard error & 0.163 & & & & \\
\hline F-statistic & & $494.532^{* * *}$ & $576.304^{* * *}$ & $705.562^{* * *}$ & \\
\hline First-stage regression F-statistic & 35.98 & 49.14 & 551.13 & 551.13 & \\
\hline \multicolumn{6}{|c|}{ P-value of the Arellano-Bond test for the first differences of variables: } \\
\hline $\operatorname{AR}(1)$ & & & & & 0.0004 \\
\hline $\operatorname{AR}(2)$ & & & & & 0.6824 \\
\hline Sargan test (p-value) & & & & & 0.07 \\
\hline
\end{tabular}

Note: ${ }^{*}$ - p-value $<0.1,{ }^{* *}-$ p-value $<0.05,{ }^{* * *}$ - p-value $<0.01$. The level of urbanisation was also taken into account as a control variable which turned out to be insignificant in all specifications.

Source: authors' calculations using the R environment

Despite the implementation of the programme, in 2015, the weighted average mortgage rate was $0.9 \mathrm{pp}$ higher than in 2014 , which is explained by the sharp increase in the key rate. In most regions, real estate prices decreased while the programme 
was in effect, so it is logical to expect an improvement in housing affordability. Now, we compare the impact of the price increase caused by the implementation of the programme and of the decrease in the mortgage rate on the HAI:

$$
\begin{aligned}
\frac{d H A I}{d M R} & =\left(\frac{12 \times 3 \times 0.35 \times \text { Income }}{L T V \times 54 \times P}\right) \\
& \times\left(\frac{M R \times t \times\left(1+\frac{M R}{12}\right)^{-12 t-1}-\left(1-\left(1+\frac{M R}{12}\right)^{-12 t}\right)}{M R^{2}}\right) \\
\frac{d H A I}{d P} & =\left(\frac{3 \times 0.35 \times \text { Income } \times\left(1-\left(1+\frac{M R}{12}\right)^{-12 t}\right)}{L T V \times \frac{M R}{12} \times 54}\right) \times\left(-\frac{1}{P^{2}}\right) .
\end{aligned}
$$

Using the 2014 data, we estimated the contribution of the decrease in the mortgage rate and the increase in real estate prices caused by the programme's implementation to the change in the HAI, see Table 2.

Table 2. Comparison of the impact of the growth in real estate prices and the impact of the interest rate cut on the HAI $(L T V=0.7)$

\begin{tabular}{l|l|l|l|l|l|l|l} 
Avg_price & MR & Income & Term & $\Delta M R$ & $\frac{\text { dHAI }}{\text { dMR }} \times \Delta M R$ & $\Delta$ Avg_price & $\frac{\text { dHAI }}{\text { dAvg_price }} \times \Delta$ Avg_price \\
\hline $69,853.2$ & 12.45 & 27.412 & 179.5 & -3.5 & 0.0046 & $7,334.6(10.5 \%)$ & -0.0017 \\
\hline
\end{tabular}

Source: authors' calculations

The effect of the interest rate cut was more than two times greater than the effect of the growth in real estate prices; hence the programme was successful and contributed to an improvement in housing affordability. Some development companies also believe that the programme prevented a sharp decline in demand during the crisis period (Deryabina, 2016). Even in the context of the programme, the number of registered titles to residential premises decreased in 2015 compared with 2014.

\section{Discussion and analysis of preliminary results of the 2020-2021 government programme}

According to the Bank of Russia, in 2020, one and a half times more housing loans were issued in the country than in 2019. The record volume of loans was facilitated by the Preferential Mortgage at $6.5 \%$ programme.

Analytical agencies use different methods to estimate the housing price and its growth rate. According to Rosstat, in 2020, the average price per 1 sq. m. of primary housing increased by $12.01 \%$, and of secondary housing, by $9.47 \%$. Secondary housing prices are closely related to primary housing prices. Owners, seeing the rise 
in prices in the primary market, increase the supply price in the secondary market. Ad aggregators estimate prices using their own databases. According to CIAN (2021), in 2020 , the real estate price in the primary market increased by $18 \%$, and in the secondary market, by 16\%. According to Avito (2021a, 2021b), from December 2019 to December 2020, the average price per 1 sq. $\mathrm{m}$. in a new building increased by $19 \%$, and in secondary housing, by $8 \%$. Avito, based on ad views, estimated that the demand for new builds increased by $23 \%$, and for secondary housing, by $35 \%$. The supply in the primary market decreased by $9 \%$, and in the secondary market, by $11 \%$. The largest price increases were observed in 2020Q3-2020Q4, when the quarantine restrictions were lifted. SberIndex ${ }^{8}$ monthly estimates the median price of housing purchased through the DomClick service. According to the data, the median price per 1 sq. m. of primary housing increased by 7\%, and of secondary housing, by $14 \%$.

In this paper, so far, we have used Rosstat data, and from 2011, the housing price per 1 sq. $\mathrm{m}$. has been calculated using the corresponding indexes of the housing prices so that the data correspond to the data on the basis of which the IUE calculates the indicators of housing affordability. This approach is considered more accurate, since Rosstat changed its methodology for estimating the average price in 2011 (Kosareva and Polidi, 2019). Further, when analysing scenarios for housing purchases, we rely on the CIAN data (a large aggregator with a transparent method for calculating real estate prices; the data is similar to the data of Avito and others).

The HAI during the period under review shows an upward trend (Figure 8). It is calculated as the ratio of a family's income to the income required for taking out a mortgage and does not take into account ability to save for a down payment.

Figure 8. Dynamics of the HAl and the main factors of housing affordability
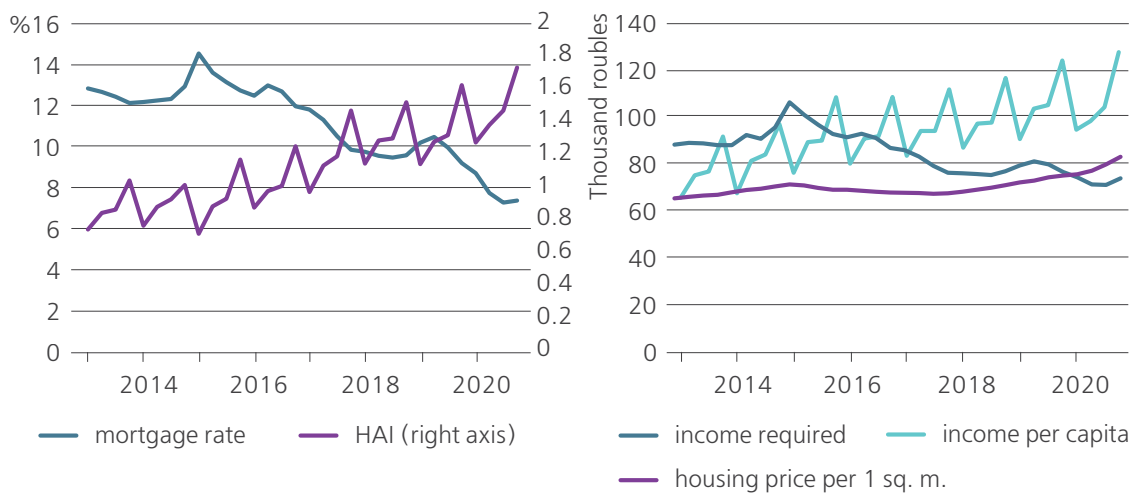

Source: compiled by the authors

Now, we compare the total cost of a mortgage loan before and after the launch of the programme for three different housing purchase scenarios - in Moscow, in St. Petersburg, and in another region.

\footnotetext{
${ }^{8}$ See https://sberindex.ru/en
} 
Figure 9. Dynamics of borrower's monthly payment and total costs in Moscow

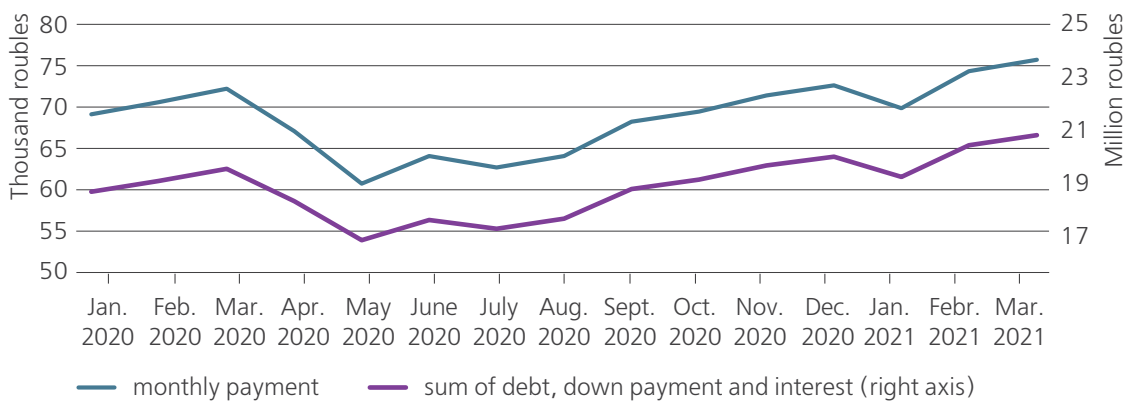

Source: authors' calculations based on data from the Bank of Russia and CIAN

Scenario 1: Purchase in Moscow of a 54 sq. m. apartment at the city's average price per square metre and interest rate for housing under construction. The calculation includes a loan term equal to 20 years and a down payment equal to $20 \%$ of the apartment price. If the purchase was carried out before November 2020, then the purchaser managed to benefit from the programme: the total cost of purchasing a home was less than it was in March 2020 without the effect of the programme. In December, the average monthly mortgage payment exceeded the same indicator in March 2020. In addition, in October 2020, the price of an apartment with an area of 54 sq. $\mathrm{m}$. at the average price per 1 sq. m. in Moscow exceeded 12 million roubles, the limit under the preferential mortgage programme. If we focus on the median prices for primary housing calculated by SberIndex, the turning point was February 2021. The growth rates of the monthly payment and the cost of purchasing an apartment for the year are presented in Table 3.

Table 3. Growth rate of borrower's monthly payment and the total costs compared to the same month the previous year in Moscow

\begin{tabular}{llll}
\hline & January 2021 & February 2021 & March 2021 \\
\hline Payment & $1 \%$ & $5 \%$ & $5 \%$ \\
\hline Total costs & $3 \%$ & $7 \%$ & $7 \%$ \\
\hline
\end{tabular}

Source: Bank of Russia, CIAN, authors' calculations

Figure 10. Dynamics of borrower's monthly payment and total costs in St. Petersburg

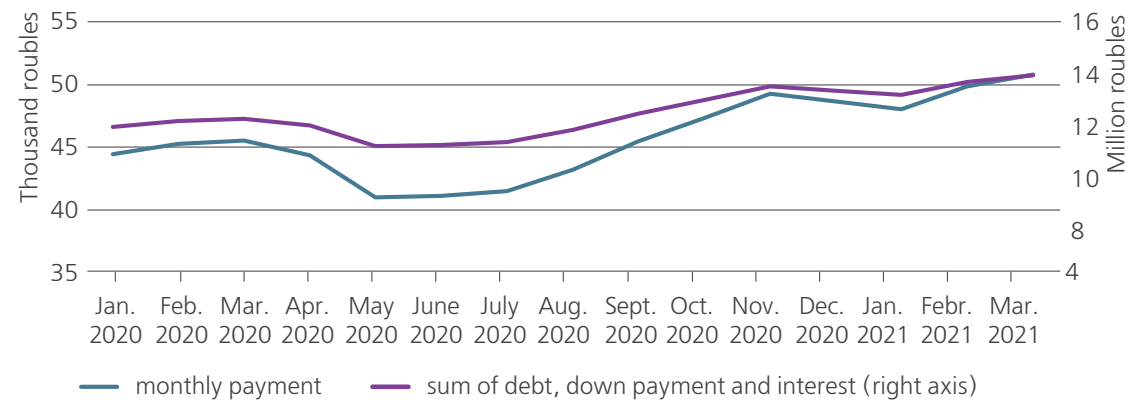

Source: Bank of Russia, CIAN, authors' calculations 
Scenario 2: Purchasing a home in St. Petersburg at average city conditions. Since September 2020, the total costs and monthly payments have exceeded those before the programme was launched. According to SberIndex, in October 2020, the borrower's costs exceeded those in March, while the amount of monthly payments exceeded those of March only in February 2021. Table 4 shows the growth rate of a borrower's monthly payment and total costs compared to the same month in the previous year in St. Petersburg.

Table 4. Growth rate of borrower's monthly payment and total costs compared to the same month of the previous year in St. Petersburg

\begin{tabular}{llll}
\hline & January 2021 & February 2021 & March 2021 \\
\hline Payment & $8 \%$ & $10 \%$ & $12 \%$ \\
\hline Total costs & $10 \%$ & $12 \%$ & $14 \%$ \\
\hline
\end{tabular}

Source: Bank of Russia, CIAN, the authors' calculations

Scenario 3: Purchasing a home in a region outside Moscow, Moscow Region, St. Petersburg, and Leningrad Region. For this calculation, the country-weighted average mortgage rate and the average price per 1 sq. $\mathrm{m}$. of housing outside the regions listed are used.

Figure 11. Dynamics of borrower's monthly payment and total costs in the regions

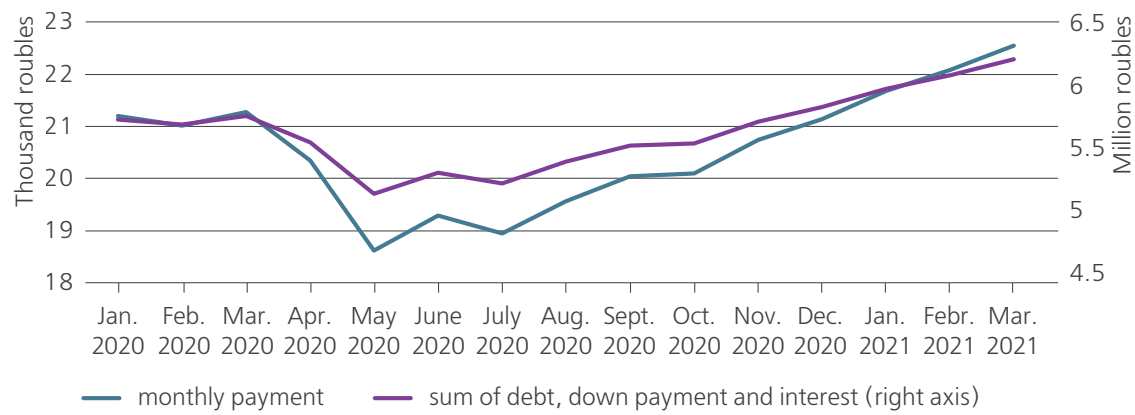

Source: Bank of Russia, CIAN, authors' calculations

From December 2020, there is no cost benefit compared to March 2020, and from January 2021, the monthly payment is higher than in March. On average across Russia, according to SberIndex, in December 2020, both indicators began to exceed those of March.

Table 5. Growth rate of borrower's monthly payment and total costs compared to the same month of the previous year in the regions

\begin{tabular}{llll}
\hline & January 2021 & February 2021 & March 2021 \\
\hline Payment & $2 \%$ & $5 \%$ & $6 \%$ \\
\hline Total costs & $4 \%$ & $7 \%$ & $8 \%$ \\
\hline
\end{tabular}

Source: Bank of Russia, CIAN, authors' calculations 
In analysing these scenarios, we must take into account the change in the average per capita income of the population. According to Rosstat, ${ }^{9}$ in Moscow, from 2019Q4 to 2020Q4, nominal average income per capita increased by $6 \%$, in St. Petersburg, by $4 \%$, and on average in Russia, by $3.4 \%$. In absolute terms, the growth in the down payment amount is not compensated by the growth in nominal average income per capita, but greatly exceeds it. In general, over the year, the real disposable income of Russians fell by $2.8 \%$. It follows from the calculations that people who managed to purchase housing in 2020Q2-2020Q3 could indeed benefit both in terms of monthly payments and of the sum of the price of housing and the interest accrued. After that, the increase in prices in many regions offset the increased availability of loans due to the programme, and a person who did not have time to complete a transaction in time could incur even higher costs than before the launch of the programme. One reason for this 'time lag' may be a lack of financial knowledge and an excessive focus on the actions of others.

In general, the 2020-2021 preferential mortgage programme caused a sharp increase in demand and, as a result, in housing prices in Russia. The population purchased housing not only for their own needs, but also for investment purposes. Real estate experts believe that the potential demand for mortgage lending has been exhausted, and a decline in demand is expected after the completion of the programme. ${ }^{10}$ In addition, an increase in mortgage rates can be expected. ${ }^{11}$ The main difference between the 2020-2021 programme and the previous one is that it was carried out in the context of monetary policy easing, while in 2015 there was a record increase in the key rate up to $17 \%$ per annum. A number of analysts believe that with the low key rate that existed in 2020, there was no need for a preferential mortgage programme and additional stimulation of demand (IRN.ru, 2021).

\section{Conclusion}

The mortgage lending market in Russia is young relative to those in European countries. It is in its formation stage and is actively growing, and increasing the availability of mortgage loans has become one of the main channels for improving housing affordability. At the same time, government regulations may have ambiguous effects. Even such a seemingly positive measure as a mortgage rate subsidy may turn out to be ineffective and even harmful, since it entails an increase in demand, and, consequently, an increase in housing prices. Despite the importance of this topic, it is relatively poorly researched.

\footnotetext{
${ }^{9}$ See at https://rosstat.gov.ru/folder/13397 (in Russian).

${ }^{10}$ See, e.g, https://www.novostroy.ru/news/comments/bum-na-zhile-v-2020-om-sprovotsirovalmnogoletniy-krizis-bedneyushchee-naselenie-snova-nachnet-pokupat-kvartiry-tolko-cherez-dvagoda/ (in Russian; accessed on 21 July 2021).

${ }^{11}$ According to the Bank of Russia forecast, the key rate will average $7.3-8.3 \%$ per annum in 2022 and will return to its long-term neutral range (5-6\%) no earlier than in the middle of 2023 , see at https://cbr.ru/eng/press/event/?id=12362
} 
This paper considered various factors of housing affordability, which can be conventionally divided into three groups: economic factors, social and demographic factors, and factors of government regulation. We compared the indicators of accessibility most used in our country and chose the ones that were suitable for this research: the HAI and the share of families with the ability to purchase housing with mortgage loans. In the main part of the paper, we evaluated the impact of two mortgage rate subsidy programmes, carried out in 2015-2016 and 2020-2021, on housing affordability. The result of designing implementation of the econometric analysis for the 2015-2016 programme concluded that, in general, the programme was successful and contributed to improved housing affordability. A decrease in mortgage rates leads to an increase in real estate prices, but despite this, during the implementation of the programme, the price of real estate remained almost unchanged, and in some regions even decreased due to a decrease in demand during the crisis period. In December 2014, due to the fall of the rouble, the key rate was raised to $17 \%$. The 2015-2016 mortgage rate subsidy programme hindered the growth of mortgage rates and, as a result, the decline in demand for housing. The 2020-2021 programme was introduced during an epidemic and a period of isolation, and its goal was also to prevent a decline in demand for housing. The main difference between this programme and the previous one is that it was carried out against the background of a low key rate compared to historical values. As a result, in 2020, real estate prices have increased by more than $10 \%$ compared to the previous year. The HAI grew, but the total cost of mortgage also increased, while the nominal income of the population remained almost unchanged. The programme had an ambiguous impact on housing affordability, since up until a certain (depending on region) moment, borrowers had the opportunity to benefit from the subsidy provided, both in terms of monthly payments and in terms of the sum of the price of housing and the interest accrued.

As a result of the analysis of both programmes, the following recommendations can be laid out to increase the effectiveness of measures of government support for housing affordability. First, before making a decision to launch a new support programme, it is necessary to assess the economic situation in the country as a whole and in the regions, and only after that draw conclusions about the timeliness of the launch. For example, if the key rate is low, subsidised mortgage rates may have undesirable consequences. Second, before a programme is launched, the monitoring indicators, and the critical values at which the programme will be terminated ahead of schedule, should be approved. In this way, an upper bound on the rate of growth in housing prices can be set. Third, methods that indirectly affect the improvement of housing affordability, such as increasing the income of the population, can be used. This approach requires more time and probably more investment, but its effect will be longer term and will not cause an increase in the population's debt burden. According to Bank of Russia analysts (Akhmetov et al., 2020), the goals of the Housing and Urban Environment National Project can be achieved if, within five years, the incomes of the population increase by $5 \%$ per year. Another approach proposed in this paper is the 
reduction of construction costs. Fourth, one of the priority objectives should be to increase the financial literacy of the population. The more economically reasonable and rational decisions the population makes, the better the market mechanism for regulating housing prices will work.

One area for further analysis is the use of microdata at the household level, as is done in foreign literature. In addition, in a short time, it will be possible to perform econometric modelling of the impact of the 2020-2021 programme on housing affordability. It is likely that it will have long-term consequences, since, first, there was an increase in the key rate and, second, during its implementation, the potential demand for housing was practically exhausted.

\section{Appendices are available at http://rjmf.econs.online/en; doi.org/10.31477/rjmf.202104.98}

\section{References}

Anundsen, A. K. and Jansen, E. S. (2013). Self-Reinforcing Effects between Housing Prices and Credit. Journal of Housing Economics, 22(3), pp. 192-212.

Akhmetov, A., Morozov, A., Sinyakov, A., Saul, S., Ushakova, Y. and Chernyadyev, D. (2020). Ipoteka i dostupnost' zhil'ya [Mortgage and Housing Affordability]. Analytical Note Bank of Russia, 2020. [In Russian].

Avito (2021a). Itogi 2020 goda na rynke novostroyek: spros vyros, predlozheniye sokratilos [Results of 2020 in the Market of New Buildings]. Avito for Business [In Russian]. https://www.avito.ru/blog/novostroyki-itogi [accessed on 12 July 2021].

Avito (2021b). Kakim stal 2020 god dlya vtorichnoy nedvizhimosti [What 2020 has Become for Resale Properties]. Avito for Business [In Russian]. https://www.avito.ru/blog/vtorichnaya-nedvizhimost-2020 [accessed on 12 July 2021].

Basten, C. and Koch, C. (2015). The Causal Effect of House Prices on Mortgage Demand and Mortgage Supply: Evidence from Switzerland. Journal of Housing Economics, 30, pp. 1-22.

Bujang, A. A., Zarin, H. A. and Jumadi, N. (2010). The Relationship between Demographic Factors and Housing Affordability. Malaysian Journal of Real Estate, 5(1), pp. 49-58.

Caldera Sánchez, A. and Andrews, D. (2011). The Evolution of Homeownership Rates in Selected OECD Countries: Demographic and Public Policy Influences. OECD Journal: Economic Studies, 2011(1), pp. 1-37.

CIAN (2021). Itogi i prognozy ot Tsian: «pervichka», «vtorichka», arenda, «zagorodka» [Real Estate Market: Results and Forecasts of CIAN Analytical Centre]. CIAN. ru, 6 January. [In Russian]. https://ryazan.cian.ru/stati-itogi-i-prognozy-ot-tsianpervichka-vtorichka-arenda-zagorodka-313591/ [accessed on 21 July 2021].

Consulting Center DOM.RF (2021). Po itogam 2020 goda vydano boleye 370 tysyach l'gotnykh ipotechnykh kreditov [In 2020, More Than 370,000 Preferential Mortgage Loans Were Issued]. [Online], [In Russian]. https://xn--hlalcedd.xn--d1aqf.xn-plai/news/po-itogam-2020-goda-vydano-bolee-370-tysyach-lgotnyh-ipotechnyhkreditov/ [accessed on 21 July 2021]. 
Damen, S., Vastmans, F. and Buyst, E. (2016). The Effect of Mortgage Interest Deduction and Mortgage Characteristics on House Prices. Journal of Housing Economics, 34, pp. 15-29.

Deryabina, A. (2016). L'gotnaya ipoteka pomozhet developeram prodavat' zhil'ye v obyemakh 2015 goda [Preferential mortgage will help developers sell housing in 2015 volumes]. RBC, 10 February. [In Russian]. https://www.rbc.ru/business/10/02/2016/5 6bb37e09a794758f66fdda2 [accessed on 21 July 2021].

DiPasquale, D. and Wheaton, W. C. (1994). Housing Market Dynamics and the Future of Housing Prices. Journal of Urban Economics, 35(1), pp. 1-27.

DOM.RF (2019). V Rossii vyrosla dolya semey, dovol'nykh svoimi zhilishchnymi usloviyami [In Russia, the Share of Families Who Are Satisfied with their Living Conditions Has Increased]. [Online]. 12 December. [In Russian]. https://xn--d1aqf.xn--plai/media/ news/v-rossii-vyrosla-dolya-semey-dovolnykh-svoimi-zhilishchnymi-usloviyami-/ [accessed on 14 July 2021].

Donner, C. (2000). Housing Policies in the European Union: Theory and Practice. Vienna: Donner C.

Drobyshevski, S., Narkevich, S., Pikulina, E. and Polevoy, D. (2009). Analysis of a Possible Bubble on the Russian Real Estate Market. Gaidar Institute for Economic Policy Working Papers, N 128. [In Russian].

Filippova, O. (2021). Ipoteka: itogi 2020 goda. Issledovaniye 20 krupneyshikh ipotechnykh bankov po itogam 2020 goda. Otchet Frank RG i DOM.RF [Mortgage: Results of 2020. Report of Frank RG and DOM.RF]. Frank RG, 1 February. [In Russian]. https://frankrg.com/34677 [accessed on 21 July 2021].

Fingleton, B., Fuerst, F. and Szumilo, N. (2019). Housing Affordability: Is New Local Supply the Key? Environment and Planning A: Economy and Space, 51(1), pp. 25-50. https://doi.org/10.1177/0308518X18798372

Galster, G. and Lee, K. O. (2021). Housing Affordability: A Framing, Synthesis of Research and Policy, and Future Directions. International Journal of Urban Sciences, 25(sup1), pp. 7-58. https://doi.org/10.1080/12265934.2020.1713864

Glaeser, E. L. and Shapiro, J. M. (2002). The Benefits of the Home Mortgage Interest Deduction. J. M. Poterba, ed. Tax Policy and the Economy, Vol. 17. MIT Press, pp. 37-82.

Hegedüs, J., Lux, M. and Sunega, P. (2011). Decline and Depression: The Impact of the Global Economic Crisis on Housing Markets in Two Post-Socialist States. Journal of Housing and the Built Environment, 26(3), pp. 315-333.

Hegedüs, J., Rogozhina, N., Somogyi, E., Struyk, R. and Tumanov, A. (2004). Potential Effects of Subsidy Programmes on Housing Affordability: The Cases of Budapest and Moscow. European Journal of Housing Policy, 4(2), pp. 151-184.

Higher School of Economics (2019). Delovoy klimat v stroitel'stve v III kvartale 2019 goda [Business Climate in Construction in 2019Q3]. [In Russian]. Moscow: HSE.

Hilber, C. A. L. and Turner, T. M. (2014). The Mortgage Interest Deduction and its Impact on Homeownership Decisions. Review of Economics and Statistics, 96(4), pp. 618-637.

IRN.ru (2021). Novostroyki Moskvy v 2020 godu: l'gotnaya ipoteka byla ne nuzhna [New Buildings in Moscow in 2020: Preferential Mortgages Were Not Needed]. 
IRN.ru, 28 January. [In Russian]. https://www.irn.ru/articles/41333.html [accessed on 21 July 2021].

Koblyakova, A., Hutchison, N. and Tiwari, P. (2014). Regional Differences in Mortgage Demand and Mortgage Instrument Choice in the UK. Regional Studies, 48(9), pp. 1499-1513.

Kosareva, N. B. and Polidi, T. D. (2019). Housing Affordability in Russia and Foreign Countries. Voprosy Ekonomiki, 7, pp. 29-51. [In Russian]. https://doi.org/10.32609/0042-8736-2019-7-29-51

Li, Q. and Chand, S. (2013). House Prices and Market Fundamentals in Urban China. Habitat International, 40, pp. 148-153.

Maddala, G. S. and Wu, S. A. (1999). A Comparative Study of Unit Root Tests with Panel Data and New Simple Test. Oxford Bulletin of Economics and Statistics, 61, pp. 631-652.

McGibany, J. M. and Nourzad, F. (2004) Do Lower Mortgage Rates Mean Higher Housing Prices? Applied Economics, 36(4), pp. 305-313.

McQuinn, K. and O'Reilly, G. (2008). Assessing the Role of Income and Interest Rates in Determining House Prices. Economic Modelling, 25(3), pp. 377-390.

Mussa, A., Nwaogu, U. G. and Pozo, S. (2017). Immigration and Housing: A Spatial Econometric Analysis. Journal of Housing Economics, 35, pp. 13-25.

Rosen, H. S. (1979). Housing Decisions and the U.S. Income Tax: An Econometric Analysis. Journal of Public Economics, 11(1), pp. 1-23.

Russian Government (2015). Ob utverzhdenii Pravil predostavleniya subsidiy iz federal'nogo byudzheta rossiyskim kreditnym organizatsiyam i aktsionernomu obshchestvu «DOM.RF» na vozmeshcheniye nedopoluchennykh dokhodov po vydannym (priobretennym) zhilishchnym (ipotechnym) kreditam (zaymam)» [On the Rules for Granting Subsidies from the Federal Budget to Russian Credit Institutions and DOM.RF to Reimburse their Lost Incomes on Issued Mortgage Loans]: Resolution No. 220, dated 13 March 2015 (as amended 28 September 2018). [In Russian].

Russian Government (2020). Ob utverzhdenii Pravil vozmeshcheniya kreditnym i inym organizatsiyam nedopoluchennykh dokhodov po zhilishchnym (ipotechnym) kreditam (zaymam), vydannym grazhdanam Rossiyskoy Federatsii v 2020 i 2021 godakh [On Approval of the Rules for Reimbursing Credit and Other Institutions for Lost Incomes on Mortgage Loans Issued to the Russian Citizens in 2020 and 2021]: Resolution No. 566, dated 23 April 2020. [In Russian].

Sá, F. (2015). Immigration and House Prices in the UK. Economic Journal, 125(587), pp. 1393-1424. https://doi.org/doi: 10.1111/ecoj.12158

Shi, S., Jou, J. and Tripe, D. (2014). Can Interest Rates Really Control House Prices? Effectiveness and Implications for Macroprudential Policy. Journal of Banking and Finance, 47, pp. 15-28. https://doi.org/10.1016/j.jbankfin.2014.06.012

Skaburskis, A. (2004). Decomposing Canada's Growing Housing Affordability Problem: Do City Differences Matter? Urban Studies, 41(1), pp. 117-149.

Sternik, G. and Apalkov, A. (2014). Kolichestvennaya otsenka vliyaniya razlichnykh faktorov na dostupnost' zhil'ya i ipoteki [Quantitative Estimation of Different Factors Impact on Housing and Mortgage Affordability]. Urbanistica i rinok nedvigimosti, 3, pp. 6-16. [In Russian]. https://doi.org/10.7256/2313-0539.2014.3.13779 